\title{
UTILIZATION OF RECYCLED AND WASTE MATERIALS IN VARIOUS CONSTRUCTION APPLICATIONS
}

\author{
Johnny Bolden, Taher Abu-Lebdeh and Ellie Fini
}

Department of Civil, Architectural and Environmental Engineering,

North Carolina A and T State University, Greensboro, 27411, North Carolina, United States

Received 2012-12-29, Revised 2013-01-04; Accepted 2013-02-15

\begin{abstract}
More production equals more waste, more waste creates environmental concerns of toxic threat. An economical viable solution to this problem should include utilization of waste materials for new products which in turn minimize the heavy burden on the nation's landfills. Recycling of waste construction materials saves natural resources, saves energy, reduces solid waste, reduces air and water pollutants and reduces greenhouse gases. The construction industry can start being aware of and take advantage of the benefits of using waste and recycled materials. Studies have investigated the use of acceptable waste, recycled and reusable materials and methods. The use of swine manure, animal fat, silica fume, roofing shingles, empty palm fruit bunch, citrus peels, cement kiln dust, fly ash, foundry sand, slag, glass, plastic, carpet, tire scraps, asphalt pavement and concrete aggregate in construction is becoming increasingly popular due to the shortage and increasing cost of raw materials. In this study a questionnaire survey targeting experts from construction industry was conducted in order to investigate the current practices of the uses of waste and recycled materials in the construction industry. This study presents an initial understanding of the current strengths and weaknesses of the practice intended to support construction industry in developing effective policies regarding uses of waste and recycled materials as construction materials.
\end{abstract}

Keywords: Recycled Materials, Construction Materials, Environmental Concerns, Natural Resources

\section{INTRODUCTION}

Several issues exist regarding reducing waste. A key environmental issue is waste incinerators, furnaces for burning trash, garbage and ashes. These incinerators produce 210 different dioxin compounds plus mercury, cadmium, nitrous oxide, hydrogen chloride, sulfuric acid and fluorides. Produced also in incinerators is particulate matter that is small enough to remain permanently in the lungs. Additionally, waste incinerators generate more $\mathrm{CO}_{2}$ emissions than coal, oil, or natural gas-fueled power plants. For years, scientists and researchers have been searching for possible solutions to environmental concerns of waste production and pollution. Many have found that replacing raw materials with recycled materials reduces our dependency on raw materials in the construction industry. The Federal Highway Administration (FHWA) estimated that building demolition in the United States alone produces 123 million tons of construction waste per year (FHWA, 2004). Begum et al. (2010) supports the adoption of prefabrication and Industrialized Building Systems (IBS) to reduce waste generation and management problems. Their study revealed that a significant amount of material wastage can be reduced by the adoption of prefabrication and the rates of reused and recycled waste materials are relatively higher in projects that adopt prefabrication. In addition to a reduction of construction waste generation, Hassim (2009) identified and discussed other advantages of applying prefabrication in the building and construction activities. This include enhance integrity on the building design and construction, reduction unskilled workers, reduce construction cost, fixed design at the early stage North Carolina A and T State University, Greensboro, 27411, North Carolina, United States 
of design, better supervision, promote safer and more organized construction site and improve environmental performance through waste minimization. Further, from the results of the survey, one issue companies felt need addressing is the creation of a separation process on site oppose to an accumulation of all waste in one pile. A solution to this problem would be planning recycling into the pre construction plans in advance. Integrated Solid Waste Management (ISWM) is the selection and application of suitable techniques, technologies management programs to achieve specific waste management objectives and goals. Malakahmad et al. (2010) and his colleagues suggested the implementation of ISWM systems as a toll for sustainable development. They concluded that one key element of ISWM is solid waste separation, which contributes to a successful recycling program.

Several researchers from NC A\&T State University James et al. (2011); Ellie et al. (2011); AbuLebdeh et al. (2010a; 2010b); Fini and Abu-Lebdeh (2011) and Hamoush et al. (2011) and other governmental and academia agencies investigated several green materials technologies that reduce environmental effects and use recycled materials in infrastructures applications. The researchers developed several green material technology programs, which maintain or improve current practices in construction engineering and ensures green products or methods arising from these programs would be cost effective and would confer benefits on society, the economy and the environment. In order to obtain knowledge of the most advanced use of waste and recycled materials, the author reviewed these and other studies. For instance, James et al. (2011) researched the potential use of Recycled Concrete Aggregate (RCA) and Fly Ash (FA) in concrete pavement. The recycled concrete came from a demolished local site. Their research revealed that using RCA up to $25 \%$ and FA up to $15 \%$ will not have a significant difference (if any) in strength compared with concrete containing virgin aggregate. Thus, using RCA and FA in concrete pavement may promote economical and environmental benefit. Hamoush et al. (2011) investigated a new improved engineered gladding stone for better toughness, ductility, durability and thermal resistance. In their research, the back layer of the stone utilized recycled crumb rubber, which provides a combined solution for energy saving and environmental concerns. The results of adding crumb rubber showed a reduction in the material unit weight, enhanced ductility and toughness and improved thermal resistance. The stone's properties such as compressive strength, thermal conductivity, durability, impact resistance and water absorption were experimentally measured and compared with natural stone specimens. Kaosol (2010) conducted research on reusing the water treatment sludge from a water treatment plant to make hollow concrete blocks. His objectives were to increase the value of the water treatment sludge from a water treatment plant and to make a sustainable and profitable disposal alternative for the water treatment sludge. Findings showed that the production of the hollow concrete blocks mixed with water treatment sludge could be a profitable disposal alternative in the future.

This study presents results from a questionnaire survey conducted to find out what recycled and waste materials are currently being used in the construction industry and areas were construction related companies need to be informed more to increase the potential use of such materials. The focus was on applicable waste and recycling materials within four sectors, namely, Composite Waste, Industrial Sector Waste, Municipal Sector Waste and Transportation Sector Waste. Included is a comprehensive review of data, information, findings (including benefits/advantages) and evidences relative to recycling waste materials and construction applications. Each sector includes subsections of recyclable materials in relation to the construction industry. The Transportation Sector waste that can be used as beneficial recycled materials including tire rubber, reclaimed asphalt and recycled concrete aggregate. The Municipal waste sector contains beneficial materials for the construction industry including roofing shingles, glass, plastic and carpet. The Industrial waste sector contain beneficial materials including Cement Kiln Dust (CKD), foundry sand, fly ash, silica fume and slag. The composite waste sector includes swine manure, animal fat, empty palm fruit bunch, citrus peels and sewage sludge. Findings suggested the need for better documentation of the use of recycled materials and that construction industry need to develop effective policies regarding the use of waste and recycled materials as construction materials.

The main objective of this study is to investigate the effective use of recycled and waste materials in various construction applications. Goals and objectives include: (1) Review of studies of Recycled Materials in construction application; (2) Survey of current practices of uses of waste and recycled material in construction; (3) Connecting Researches and industry with an overview of what recycled materials are available for different applications and (4) Better Documentations for green infrastructures benefits 


\section{MATERIALS AND METHODS}

\subsection{Tire Rubber}

An estimated number of one billion scrap tires have been disposed of in huge piles across the United States. An additional 250 million tires unaccounted for are discarded yearly (RMA, 2011). Whole tires have been used in artificial reefs, break waters, dock bumpers, soil erosion control mats and play ground equipment. Several studies have shown that tire waste can be successfully used in concrete, grass turf, asphalt mix, embankments, stone cladding, flowable fill and clay composite.

\subsection{Reclaimed Asphalt Pavement}

The transportation sector has used Reclaimed Asphalt Pavement (RAP) for many years. In 2009, the amount of RAP used in asphalt pavements was 56.0 million tons and in 2010, 62.1 million tons. RAP is America's most recycled and reused material; currently, RAP is being recycled and reused at a rate over $99 \%$. RAP is used to backfill pavement edges, rework base and base course. According to the World Business Council for Sustainable Development, manufactures around the world produce more than 25 billion tons of concrete yearly.

\subsection{Recycled Concrete Aggregate}

The Federal Highway Administration (FHWA) projected an increase in aggregates to over 2.5 billion tons per year. Crushed aggregate has been used as base course or granular base in highway construction. Its primary function is to increase the load capacity of the pavement and to distribute the applied load to avoid damage to the sub grade.

\subsection{Roofing Shingles}

Each year, the U.S. generates approximately 11 million tons of asphalt roofing shingle scrap (CalRecycle, 2006). Use of recycled asphalt shingles (both manufacturer's waste and tear-offs) increased from 702,000 tons to 1.10 million tons from 2009 to 2010, which represents a 57\% increase. Assuming conservative asphalt content of $20 \%$ for shingles, this represents 234,000 tons (1.5 million barrels) of asphalt binder conserved. Roofing shingles are made from a fiberglass or organic backing, asphalt cement, sand-like aggregate and mineral fillers such as limestone dolomite and silica. Beneficial applications include, but not limited, to Hot Mix Asphalt (HMA), cold patch mix asphalt, aggregate substitute, base course, mineral filler and granular base stabilizer. Benefits of using roofing shingles include Lower disposal costs for shingle scrap manufactures, reduced cost in the production of HMA, improved the rutting resistance of the mixtures considerably, due to a combination of the fibers and harder asphalt and improved resistance to pavement cracking.

\subsection{Glass}

Americans generated 11.5 million tons of glass in the Municipal Solid Waste (MSW) stream in 2010. Glass is composed of silica or sand and contains some amounts of limestone and soda ash used to produce uniform quality and color. According to the Association of Cities and Regions for Recycling (ACRR), people around the world send 1.5 million tons of glass to landfills each year. Glass that ends up in the landfill won't break down for over a million years. Glass cullet creates workability problems in concrete mix and the likely hood of alkali-silica reaction. Beneficial uses are in the secondary applications, such as in the manufacture of fiberglass insulation, roadbed aggregate, driving safety reflective beads and decorative tile.

\subsection{Plastic}

In 2010, plastic waste generated approximately 31 million tons, representing $12.4 \%$ of total Municipal Solid Waste. Uses of recycled plastic in the construction industry include plastic strips to add to soil embankments, which has positive results of increasing the measured strength in reinforcement of soils. HMA mixture has a higher stability, reduced pavement deformation; increase fatigue resistance and provide better adhesion between the asphalt and the aggregate (Awwad and Shbeeb, 2007). Grinded polyethylene to provide better coating or attached easily to the aggregate as the surface area of the polymer increases.

\subsection{Carpet}

According to Carpet America Recovery Efforts (CARE) in 2010, carpet waste diverted from landfills was 338 million pounds, 271 million pounds were recycled, 3 million pounds used for alternative fuel and 23 million pounds for cement kilns. Old carpet is being recycled and used in composite lumber (both decking and sheets), tile backer board, roofing shingles, rail road ties, automotive parts, carpet cushion and stepping stones. A study by Wang et al. (2000) proved that by adding fibers to concrete, both toughness and tensile properties increased. Other benefits in adding carpet fiber to concrete include reduction of shrinkage, improved fatigue strength, wear resistance and durability. 


\subsection{Cement Kiln Dust}

CKD (byproduct of manufacturing Portland cement) is fine grained, highly alkaline waste, removed from the cement kiln exhaust gas by air pollution control devices. Uses of CKD may include: soil stabilization, waste treatment, cement replacement and asphalt pavement. CKD is perfect as soil stabilizer improving soils strength and minimizing work and cost. Siddique (2006) concluded that concrete mixtures containing low percentages $(5 \%)$ of $\mathrm{CKD}$ can achieve almost equal compressive strength, flexural strength, toughness and freezing and thawing resistance as that of the control mixture. CKD is a quality adsorbent and natural alkaline that makes it an effective waste treatment. Emery (1981) suggested that CKD (mixed with asphalt as mineral filler) can significantly reduce asphalt cement requirements between 15 and $25 \%$ by volume. CKD added to asphalt binder produces low ductile mastic asphalt and provides stripping resistance for the pavement.

\subsection{Foundry Sand}

Foundry sand is a by-product of ferrous and nonferrous metal casting. It is high quality silica sand with uniform physical characteristics. Foundry facilities operate by purchasing high quality silica sand to make casting molds and reuse the sand numerous times within the foundry. Beneficial reuse of foundry sand continues to become a more accepted practice as more end-users are introduced to the concept. Beneficial applications of foundry sand include aggregate replacement in asphalt mixtures, Portland cement concrete, source material for Portland cement, sand used in masonry mortar mixes, embankments, retaining walls, subbase, flowable fills, barrier layers and HMA mixtures.

\subsection{Silica Fume}

The environmental concerns necessitated the collection and landfilling of silica fume to be mandatory. Perhaps the most important use of this material is as mineral admixture in concrete. Silica fume is added to Portland cement concrete to improve its properties, in particular its compressive strength, bond strength and abrasion resistance. These improvements stem from both the mechanical improvements resulting from addition of a very fine powder to the cement paste mix as well as from the pozzolanic reactions between the silica fume and free calcium hydroxide in the paste.

\subsection{Fly Ash}

Fly Ash (FA) is the by-product of coal combustion in power generation. Coal provides more than half of the nation's electricity and continues to be the fuel of choice for generating power. Fly Ash is a powdery substance laced with heavy metals such as arsenic, mercury and lead. Fly ash can be an alternative to another industrial resource, process, or application. These processes and application include, but are not limited to, cement and concrete products, structural fill and cover material, roadway and pavement utilization, infiltration barrier and underground void filling. It can be used as partial replacement of cement because of its beneficial effects, such as, lower water demand for similar workability, reduced bleeding, reduce cracking at early age and lower evolution of heat. High-lime fly ash has permitted normal replacements of 25-40 and up to $75 \%$ of cement in concrete materials for parking lots, driveways and roads.

\subsection{Slag}

Slag is a co-product of the iron and steel making process. Once scorned as useless, it is now recognized as a valuable material with many uses in agriculture, environmental applications and in the construction industry. Air cooled course aggregate is used in concrete and asphalt mixes, fill material in embankments, road base material and as treatments for the improvement of soils. Ground Granulated Blast Furnace Slag (GGBFS) has a positive effect on the flexural and compressive strength of concrete. Expanded slag has low density allowing for good mechanical binding with hydraulic cement paste. Bulk density, particle size, porosity, water holding capacity and surface area makes it suitable for use as an adsorbent.

\subsection{Swine Manure}

The environmental effects of swine manure storage systems and application methods are a concern, mainly with respect to surface water, groundwater and air quality as affected by odors and gaseous emissions from large-scale swine production operations. To address these concerns scientists (Fini and co-researchers) from North Carolina A and T State University have found ways to convert swine waste into bio-binder, replacing petroleum based adhesives with bio degradable adhesive. The viscosity of bio-modified binder is significantly lower than that of non-modified binder. Reduction in the binder viscosity can improve binder wettability which in turn may improve mixture durability. Decrease in stiffness and increase in relaxation capability of binderimplies improvement in low temperature properties and reduction in low temperature cracking. By adding $2 \%$ biobinder, one can maintain high temperature grade of binder. 
Table 1. Selected recycled materials and their construction applications

\begin{tabular}{|c|c|c|c|c|c|c|c|c|c|c|c|c|}
\hline \multirow[b]{2}{*}{ Recycled material } & \multicolumn{12}{|c|}{ Innovative recycled material in construction applications } \\
\hline & $\begin{array}{l}\text { Hot mix } \\
\text { asphalt }\end{array}$ & $\begin{array}{l}\text { Concrete } \\
\text { mixes }\end{array}$ & $\begin{array}{l}\text { Embank } \\
\text { ments }\end{array}$ & Aggregate & $\begin{array}{l}\text { Base } \\
\text { course }\end{array}$ & $\begin{array}{l}\text { Mineral } \\
\text { filler }\end{array}$ & $\begin{array}{l}\text { soil } \\
\text { stabilizer }\end{array}$ & Adsorbent & $\begin{array}{l}\text { Waste water } \\
\text { treatment }\end{array}$ & Polymer & Adhesive & $\begin{array}{l}\text { Alternative } \\
\text { fuel }\end{array}$ \\
\hline Swine manure & $x$ & & & & & & & & & & & $x$ \\
\hline Animal fat & & $x$ & & & & & & & & $x$ & & \\
\hline Silica fume & $x$ & $\times$ & & & & & & & & & $x$ & \\
\hline $\begin{array}{l}\text { Roof } \\
\text { shingles }\end{array}$ & $x$ & & & $\times$ & $x$ & $x$ & $\times$ & & & & & \\
\hline Palm bunch fiber & $x$ & & & & & & & & & & & \\
\hline Citurs peels & & & & & & & & $\times$ & & & & \\
\hline Cement kiln dust & $x$ & $x$ & & & & & $x$ & & & & & \\
\hline Fly ash & & $x$ & $x$ & $x$ & & $x$ & & $x$ & $x$ & & & \\
\hline Floundry sand & $x$ & $\times$ & $x$ & $x$ & $x$ & & & & & & & \\
\hline Slag & & $x$ & $\times$ & & $\times$ & & $x$ & & & & & \\
\hline Glass & & & $x$ & $x$ & & & $x$ & & & & & \\
\hline Plastic & $x$ & & $x$ & $x$ & & & & & & & & \\
\hline Carpet & $x$ & $x$ & $x$ & & & & & & & & & \\
\hline Tire scraps & $x$ & $x$ & $x$ & & $x$ & $x$ & $x$ & $x$ & & & & $x$ \\
\hline Asphalt pavement & $x$ & & & $x$ & $x$ & & & & & & & \\
\hline Concrete Aggregate & & $x$ & & $x$ & $x$ & & & & & & & \\
\hline Gypsum & $x$ & & & & & & & & & & & \\
\hline Sewage sludge & $x$ & $x$ & & & & & & & & & & \\
\hline
\end{tabular}

\subsection{Animal Fat}

The use of animal fat has been used in the construction industry since roman times. Animal fat also referred to as tall oil. TOP has a strong connection with cement providing a chemical adsorption interaction.

\subsection{Citrus Peels}

The US 2006/2008 seasons of citrus juice production generated 10.6 million metric tons of waste. Research shows that citrus peel can be an alternative to commercial activated carbon that is high in capital and regeneration costs, which is the preferred absorbent for removal of Methylene Blue (MB). $\mathrm{MB}$ is a dye that comes from the wastewater from textile industries and can cause severe environmental pollution if emitted to the environment without proper treatment.

\subsection{Sewage Sludge}

Course solids and bio solids accumulated in a wastewater treatment process must be treated and disposed of in a safe and effective manner-creating sewage sludge. This material may be inadvertently contaminated with toxic organic and inorganic compounds. However, sludge ash has been investigated in the production of concrete. Results of several studies have indicated the benefits of using sewage slag ash in concrete such as compressive strength, freeze- thaw resistance and good hardening properties. Sewage sludge ash may be used as a mineral filler substitute or as a portion of the fine aggregate in hot mix asphalt paving.

Summary of selected recycled materials and their applications in different construction project is tabulated in Table 1.

\subsection{The Survey}

Sustainable-green infrastructure is growing concept of saving energy, natural resources and cost, as well as in the solution to environmental concerns involving waste. In order to accomplish the growing industry of green infrastructure, the end users including contractors, engineers and suppliers have to be informed about what recycled/waste materials are available to use in the construction industry. To find out what end users are aware of recycled and waste materials and who are actually using them, companies have to be approached and questioned. The survey intends to reveal the barriers or issues behind not using recycled materials in the construction industry. Results of the survey presents an 
initial understanding of the current strengths and weaknesses of the practice intended to support construction industry in developing effective policies regarding uses of waste and recycled materials as construction materials.

\subsection{Methodology}

A questionnaire survey was conducted through phone calls, visits and email, addressing: (1) If the company uses or sells any waste or recycled materials for construction application, (2) Is the surveyor aware of other recycled materials that are being used in construction applications, (3) Are there any recycled materials that are not recommended for use in the construction industry and (4) if not using such materials, what are the barriers behind not using recycled materials in their work. All the questions ended with a yes for what application and if no, reasons for not using the material. The survey consisted of a list of recycled and waste materials including; Cement Kiln Dust (CKD), fly ash, foundry sand, slag, glass, plastic, carpet, tire rubber, recycled asphalt, recycled concrete, gypsum, silica fume, swine manure, animal fat, soy bean, roofing shingles, citrus peels, sewage sludge, date and oil palm tree and a place to add additional recycled materials being used in the construction industry not listed. The last question was included to record any additional contact or references to question for more information on the topic.

\section{RESULTS}

The survey was compiled of 65 participants from 50 companies. The companies surveyed consisted of contractors, engineers, architects and suppliers of concrete, asphalt, landfills, scrap yards, steel manufactures, drilling, demolition and recycling companies. Table 2 shows the percentage for each type of company surveyed. Figure 1 shows responses of the surveyed companies on the most common recycled materials. From this sample of companies, the most common recycled material was Recycled Concrete at 15\%; followed by Recycled Asphalt and Wood, with 12 and $8 \%$ respectively. Seven percent of the companies did not use recycled material at all. There were a few companies that were not included in the graph. These companies used less than $2 \%$ of any given recycled material including tire rubber, silica fume, glass, cement kiln dust, carpet, foundry sand, swine manure, animal fat, soy bean, citrus peels, sewage sludge and date and oil palm tree, which were listed in the survey as usable recyclable materials for construction applications. Other materials that were mentioned that had a low percentage usage were cast iron, copper, brass and sawdust.

Figure 2 shows the percentages of the most commonly recycled materials used in concrete. Recycled concrete was found to be the most popular at 54\%, the cost is low compared to purchasing natural stones and aggregate and its availability is high because of demolition of older buildings and highways. It should be noted that, in order for concrete to be recycled and reused as aggregate, it must be cleaned and washed for DOT approval. Fly ash was very popular, with $20 \%$ of companies using it in concrete. Companies noted that FA is a great substitute for cement and it is cost effective. Some companies mentioned slag (12\%) and silica fume (9\%) for special projects, varying use according to the engineer from job to job bases. Tire rubber (4\%) was found to be used in concrete including concrete barrier applications. One company considered using cement kiln dust and glass in their concrete, based on information provided to them by the National Ready Mix Association, but has yet to complete a testing strip. Companies using recycled asphalt $(57 \%)$, grinded the old asphalt into course and fine course, then applied it to the new asphalt paving process.

Another company mentioned that they reuse up to $40 \%$ recycled asphalt. Figure 3 shows the most commonly used material in asphalt. There is also high percentage of recycling roofing shingles (36\%) that asphalt companies use.

Of all the companies surveyed, $7 \%$ explained that they did not use recycled materials due to cost, lack of education regarding certain materials, limited to special cases, environmental, quality of the product, contamination, permits, separation process, lack of market to buy the material, no equipment, storage, sent to scrap yards and landfills and availability. Figure 4 shows the percent of reasons why companies are not using recycled materials.

The companies surveyed, felt that cost made up $22 \%$ of the reasons why they do not use certain recycled materials in the construction industry. The cost outweighs the benefits for using certain recycled materials. Some processes are expensive to operate including glass and the recycling tire scraps. Following cost, companies claimed lack of education to be $13 \%$ of the reason why certain recycled materials aren't being used in construction applications. Many companies are unfamiliar or not sure of what recycled materials can be used in construction applications. Environmental constituted for $11 \%$ of the reasons. 


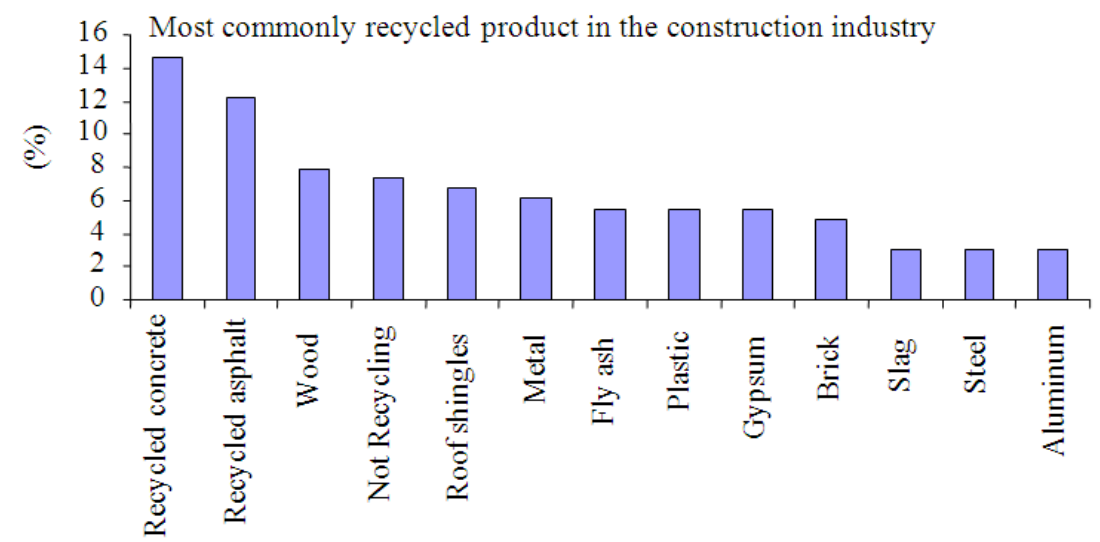

Fig. 1. Most commonly used recycled materials for construction applications

Most commonly recycled material used in concrete

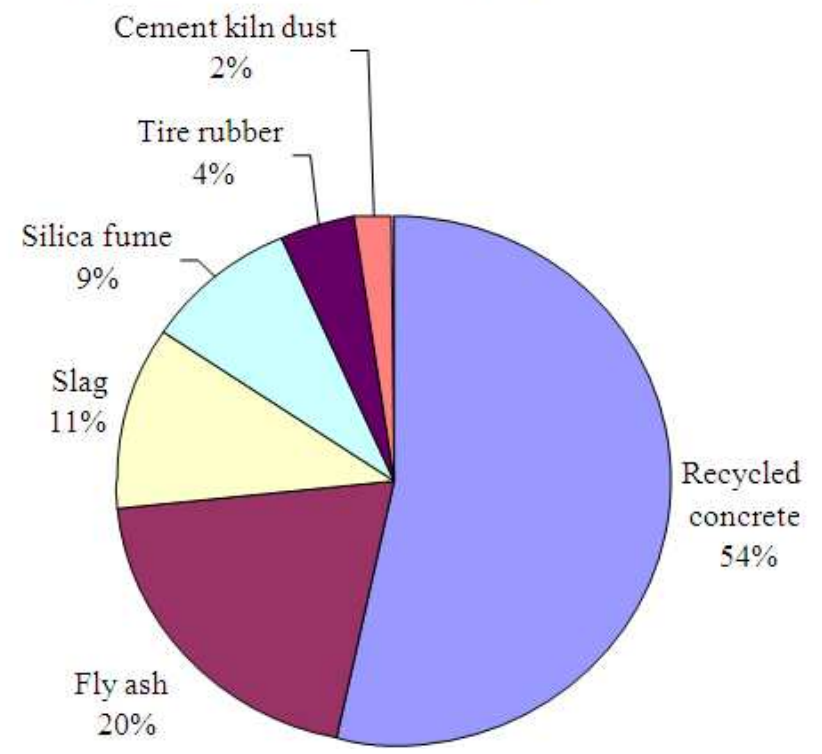

Fig. 2. Most commonly used recycled material in concrete

Most commonly used recycled material in asphalt paving

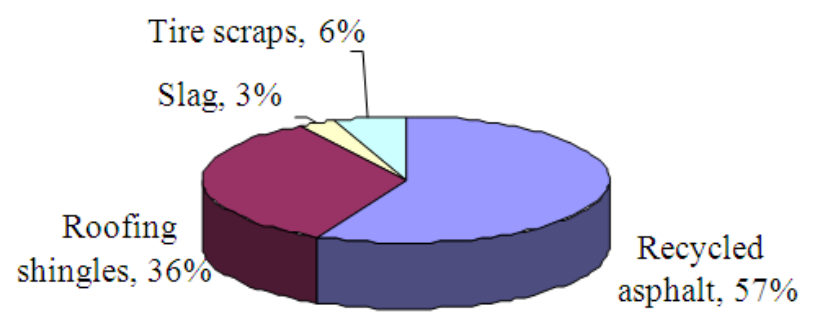

Fig. 3. Most commonly used recycled material in asphalt paving 


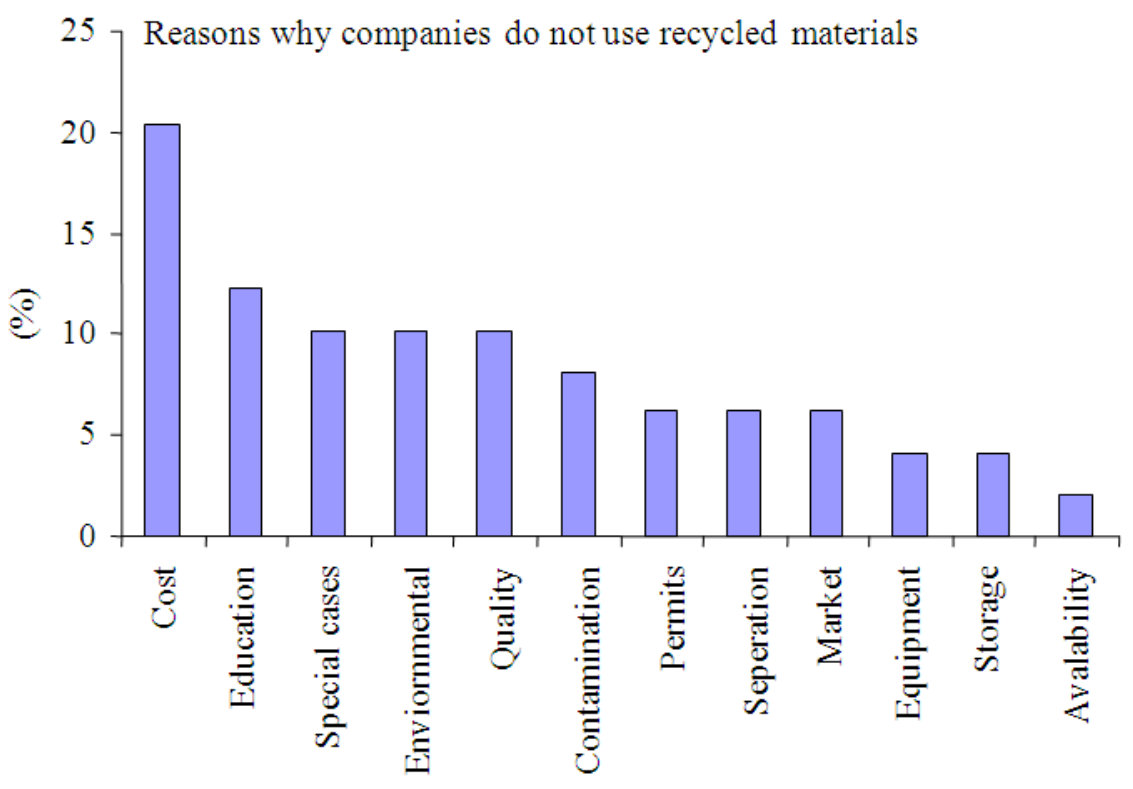

Fig. 4. Reasons of not using recycled materials

Recycled materials that companies are aware of

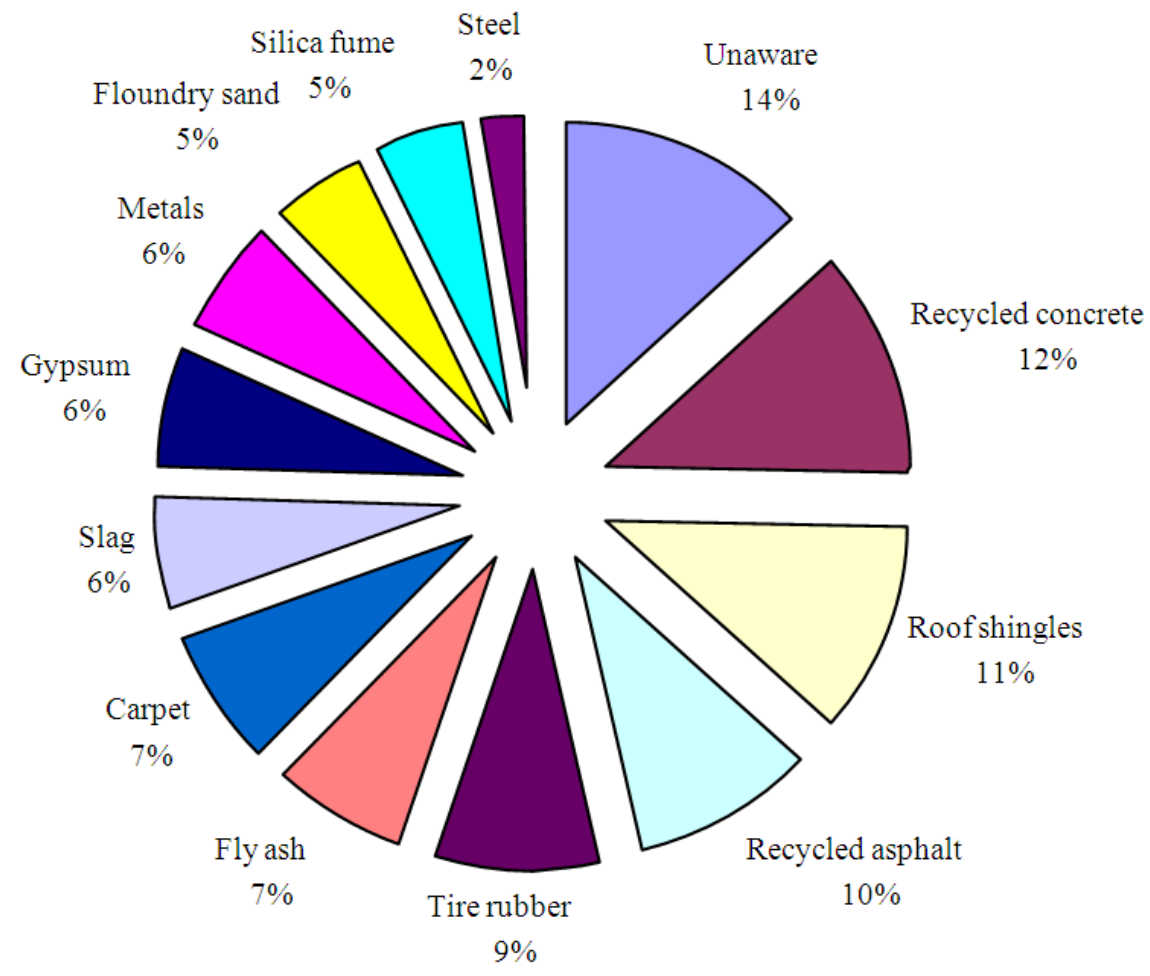

Fig. 5. Awareness of Recycled materials for construction applications 


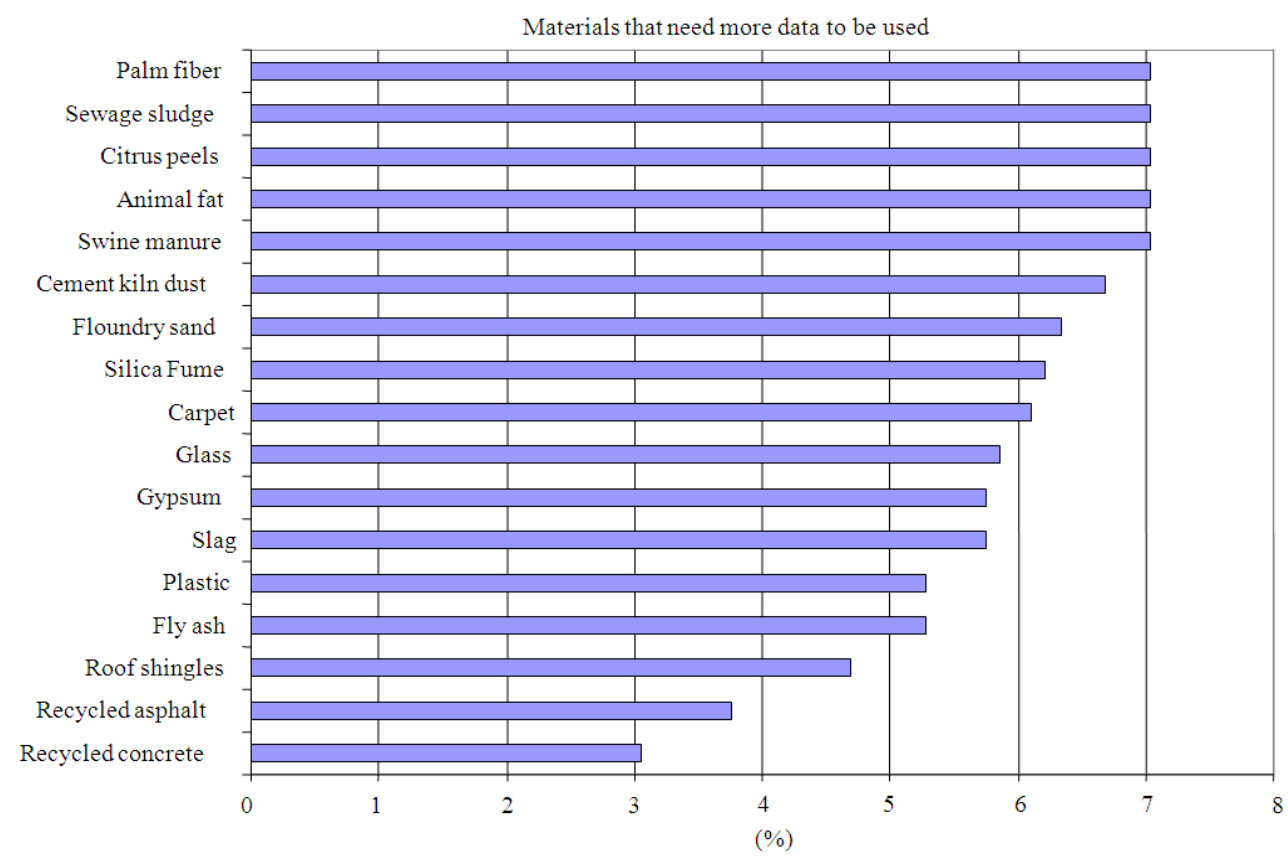

Fig. 6. The percent of materials that need more data

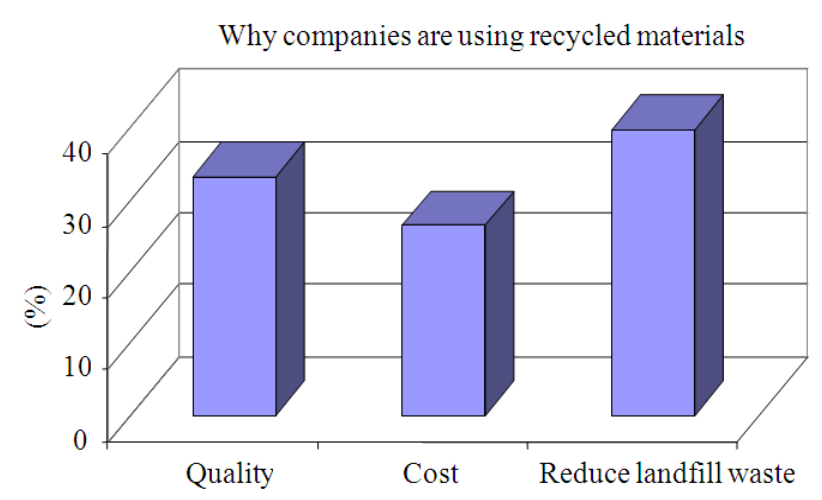

Fig. 7. Why companies are using recycled materials

Environmental hazards include fly ash which contains traces of arsenic and mercury, roofing shingles containing asbestos and molding issues in some gypsum. Quality of end products represents $11 \%$ of the reasons why recycled materials were not utilized. Contamination, which makes $8 \%$ of the reasons, was another issue of not using recycled materials due to the reduced performance of the applications. The need to have permit for certain waste materials, high cost of the separation process and lack of marketing of the recycled material each represents $7 \%$ of why companies choose not to use recycled materials.
Table 2. Types of applications

\begin{tabular}{lcc}
\hline Application & No. & Percentage \\
\hline Recycling & 20 & 31 \\
Construction & 11 & 17 \\
Concrete & 9 & 14 \\
Contractors & 6 & 9 \\
Asphalt & 5 & 8 \\
Engineer & 4 & 6 \\
Manufacture & 4 & 6 \\
Architect & 2 & 3 \\
Salvage & 1 & 2 \\
Association & 1 & 2 \\
Trucking & 1 & 2 \\
Steel & 1 & 2 \\
Total & 65 & 100 \\
\hline
\end{tabular}

Findings show that $14 \%$ of the companies are completely unaware of other recycled materials being used in construction. This suggests the need for education and awareness programs to introduce the availability and applicability of the recycled materials. Figure 5 shows the percentage of materials the companies are aware of in the construction industry

There are many other materials were not mentioned in this survey, but can be used in different construction projects. Recycled materials such as date and oil palm, sewage sludge, citrus peels, soy bean, animal fat, polyester lumber, rice husk and swine manure were 
among other materials that are poorly documented. The reason for the underuse can be traced to new researches and the lack of government approved regulations for these materials, especially on state and government level projects. In order to accelerate the growth of the use of recycled materials in the construction industry, surveyed companies suggested the need for more data to support materials' performance. Out of 50 companies surveyed, results indicated the areas that need more research, analysis and data before the use in construction application as shown in Fig. 6.

When companies were asked about the benefits of using recycled materials, reducing landfill waste was number one at $38 \%$ followed by quality at $33 \%$ then reduced cost at $27 \%$. They attribute the quality to some recycled materials that can improve strength such as silica fume which can be used to produce high strength concrete; fly ash improves the workability of the concrete; and crumb rubber to improve thermal resistance. Cost may be reduced by using recycled materials comparing to raw materials. Figure 7 shows the results on why companies are using recycled materials.

\section{DISCUSSION}

\subsection{Statistical Analysis}

As aforementioned, 65 participants from 50 different construction related companies participated in this study.

Table 3. Percent use of recycled material

\begin{tabular}{lrlr}
\hline Material & $\%$ & Material & $\%$ \\
\hline Recycled concrete & 15.0 & Recycled asphalt & 12.0 \\
Wood & 8.0 & Shingles & 7.0 \\
metal & 6.0 & Fly ash & 5.8 \\
Gypsum & 5.8 & Brick & 5.0 \\
Slag & 3.0 & Steel & 3.0 \\
Aluminum & 3.0 & glass & 1.0 \\
Silica fume & 2.0 & Tire rubber & 1.0 \\
Klink dust & 2.0 & Foundry sand & 1.0 \\
Carpet & 2.0 & Soy bean & 2.0 \\
Swine manure & 0.0 & Animal fat & 0.0 \\
Citrus peal & 0.0 & Sewage sludge & 1.0 \\
\hline
\end{tabular}

Table 4. Reasons of not using recycled materials

\begin{tabular}{lrlr}
\hline Reason & $\%$ & Reason & $\%$ \\
\hline Cost & 22 & Marketing & 7 \\
Lack of education & 13 & Equipment & 4 \\
Hazards & 11 & Storage & 4 \\
Quality of end product & 11 & Availability & 2 \\
Contamination & 8 & Personal & 10 \\
Permits & 7 & & \\
\hline
\end{tabular}

Table 3 and 4 summarize the statistical findings of the survey. Table 3 was generated from the responses of companies that use recycled material and shows the percent use of recycled material in different construction applications, while Table $\mathbf{4}$ was generated from responses of companies that do not use recycled materials and shows the reasons why such companies do not use recycled materials in their products or applications.

\section{CONCLUSION}

Review of several studies suggested that the use of recycled materials has positive impact through different aspects. This include the benefits in enhancing sustainability of the construction industry while reducing cost, providing solutions to environmental pollution and reducing the need for natural resources. In this study, a questionnaire survey was conducted to find out the current practices in using waste and recycled materials in the construction industry. Results indicated that some companies were not aware of the availability, quality of the materials' performance, cost savings, or any other benefits including environmental benefits. It is, thus recommended to create better documentation for green infrastructure, connecting researches and industry with an overview of what recycled materials are available for different construction applications. Companies need to be innovative in their use of recycled materials and reduce their dependency on raw materials. Also, more data and better documentations are needed to encourage the use of waste and recycled materials in the construction industry.

\section{REFERENCES}

Abu-Lebdeh, T., S. Hamoush, W. Heard and B. Zornig, 2010a. Effect of matrix strength on pullout behavior of steel fiber reinforced very-high strength concrete composites. Constr. Build. Mater. J., 25: 39-46. DOI: 10.1016/j.conbuildmat.2010.06.059

Abu-Lebdeh, T., S. Hamoush and B. Zornig, 2010b. Rate Effect on pullout behavior of steel fibers embedded in very-high strength concrete. Am. J. Eng. Applied Sci., 3: 454-463. DOI: 10.3844/ajeassp.2010.454.463

Awwad, M.T. and L. Shbeeb, 2007. The use of polyethylene in hot asphalt mixtures. Am. J. Eng. Applied Sci., 4: 390-396. DOI: 10.3844/ajassp.2007.390.396

Begum, R.A., S.K. Satari and J.J. Pereira, 2010. Waste generation and recycling: Comparison of conventional and industrialized building systems. Am. J. Environ. Sci., 6: 383-388. DOI: 10.3844/ajessp.2010.383.388 
CalRecycle, 2006. Asphalt roofing shingles recycling: Introduction. The California Department of Resources Recycling and Recovery.

Ellie, H., I. Fini, L. Al-Qadi, T. Abu-Lebdeh and J.F. Masson, 2011. Use of surface energy to evaluate adhesion of bituminous crack sealants to aggregates. Am. J. Eng. Applied Sci., 4: 244-251. DOI: 10.3844/ajeassp.2011.244.251

Emery, J.J., 1981. Potential uses for kiln dusts. Proceedings of the Symposium on Mineral Fillers, Ontario Research Foundation, (MFORF' 81), Toronto.

FHWA, 2004. Transportation Applications of Recycled Concrete Aggregate. 1st Edn., Federal Highway Administration, Washington, DC., pp: 38.

Fini, E. and T. Abu-Lebdeh, 2011. Bonding property of bituminous crack sealants in the presence of water. Am. J. Eng. Applied Sci., 4: 124-129. DOI: 10.3844/ajeassp.2011.124.129

Hamoush, S., T. Abu-Lebdeh, M. Picornell and S. Amer, 2011. Development of sustainable engineered stone cladding for toughness, durability and energy conservation. Constr. Build. Mater., 25: 4006-4016. DOI: 10.1016/j.conbuildmat.2011.04.035

Hassim, S.J.M.S.A., 2009. The contractor perception towers industrialized building system risk in construction projects in Malaysia. Am. J. Applied Sci., 6: 937-942. DOI: 10.3844/ajassp.2009.937.942
James, M.N., W. Choi and T. Abu-Lebdeh, 2011. Use of recycled aggregate and fly ash in concrete pavement. Am. J. Eng. Applied Sci., 4: 201-208. DOI: 10.3844/ajeassp.2011.201.208

Kaosol, T., 2010. Reuse water treatment sludge for hollow concrete block manufacture. Energy Resou. J., 1: 131-134. DOI: 10.3844/erjsp.2010.131.134

Malakahmad, D., D. Amirhossein, C.M. Nasir, Z. Zaki and M. Kutty et al., 2010. Solid waste characterization and recycling potential for university technology PETRONAS academic buildings. Am. J. Environ. Sci., 6: 422-427. DOI: 10.3844/ajessp.2010.422.427

RMA, 2011. U.S. scrap tire management summary. Rubber Manufacturers Association, Inc.

Siddique, R., 2006. Utilization of Cement Kiln Dust (CKD) in cement mortar and concrete-an overview. Resources Conservation Recycl., 48: 315-338. DOI: 10.1016/j.resconrec.2006.03.010

Wang, Y., H. Wu and V.C. Li, 2000. Concrete reinforcement with recycled fibers. J. Mater. Civil Eng., 12: 314-319. DOI: 10.1061/(ASCE)08991561(2000)12:4(314) 